\title{
Association of Pre-Transplant Angiopoietin-2 Index with the Risk of Acute Graft-Versus-Host Disease after Hematopoietic Stem Cell Transplantation
}

\author{
Pre-transplant Anjiyopoietin-2 Indeksinin Hematopoietik Kök Hücre Transplantasyonu \\ Sonrası Akut Graft Versus Host Hastalığı Riski ile llişkisi
}

\author{
(D) Özlem Satırer¹, (D Inci Cevher Zeytin2, (D) Berna Alkan², (D) Jale Karakaya4, (D) Duygu Çetinkaya2,3, (D) Fatma Visal Okur2,3 \\ ${ }^{1}$ Hacettepe University Faculty of Medicine, Department of Pediatrics, Ankara, Turkey \\ ${ }^{2}$ Hacettepe University, Center for Stem Cell Research and Development (PEDI-STEM), Ankara, Turkey \\ ${ }^{3}$ Hacettepe University Faculty of Medicine, Department of Pediatrics, Division of Pediatric Hematology and Bone Marrow Transplantation Unit, \\ Ankara, Turkey \\ ${ }^{4}$ Hacettepe University Faculty of Medicine, Department of Biostatistics, Ankara, Turkey
}

\section{Abstract}

Objective: Angiogenic factors (AFs) released under endothelial stress are reflective of tissue healing, while some may also contribute to tissue damage/inflammation. We investigated whether alterations in the pre-transplant levels of AFs were associated with the risk of acute graft-versus-host disease (aGvHD).

Materials and Methods: The pre-conditioning plasma levels of angiopoietin-2 (Ang2), endoglin, and follistatin were measured for 37 patients together with inflammatory markers. The index values defined were evaluated to better identify the alterations.

Results: The patients had higher pre-conditioning levels of Ang2, endoglin, and follistatin compared to controls. The patients with aGvHD had higher Ang2 index and lower albumin index scores in comparison to those without aGvHD. Multivariate analysis revealed that the pre-transplant Ang2 index was an independent risk factor for aGvHD development.

Conclusion: Pre-transplant evaluation of plasma Ang2 levels along with inflammatory status even before conditioning is associated with endothelial vulnerability. The pre-transplant Ang2 index could be a promising candidate to estimate the risk of aGvHD.

Keywords: Graft-versus-host disease, Angiopoietin-2, Angiogenesis, Inflammation, Hematopoietic stem cell transplantation

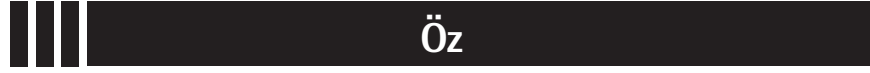

Amaç: Endotelyal stres altında salınan anjiyojenik faktörler (AF), doku iyileşmesini yansıtırken, bazıları doku hasarına/iltihabına katkıda bulunabilir. $\mathrm{Bu}$ çalışmamızda pre-transplant $\mathrm{AF}$ düzeylerindeki değişikliklerin akut graft versus host hastalığı $(\mathrm{aGvHH})$ riski ile ilişkili olup olmadığını araştırdık.

Gereç ve Yöntemler: Otuz yedi hastada plazma anjiyopoietin-2, endoglin ve follistatin seviyeleri, enflamatuvar belirteçlerle birlikte hazırlama rejimi öncesi değerlendirildi. Tanımlanan indeks değerleri AF düzeylerindeki değişiklikleri daha iyi tespit edebilmek için kullanıldı.

Bulgular: Kontrollere kıyasla hastaların nakil öncesi bakılan Ang2, endoglin ve follistatin seviyeleri daha yüksekti. aGvHH gelişen hastalarda, gelişmeyenlere kıyasla daha yüksek Ang2 indeks ve daha düşük albümin indeks değerleri saptandı. Çok değişkenli analizler, pre-transplant Ang2 indeksinin aGvHH gelişimi için bağımsız bir risk faktörü olduğunu ortaya koydu.

Sonuç: Plazma Ang2 düzeylerinin nakil öncesi hatta hazırlama rejimi verilmeden önce enflamatuvar durum ile birlikte değerlendirilmesi endotelin hasara yatkınlığı hakkında bilgi verebilir. Pre-transplant Ang2 indeksi, aGvHH riskini tahmin etmek için kullanabilecek bir belirteç olabilir.

Anahtar Sözcükler: Graft versus host hastalığı, Anjiyopoietin-2, Anjiogenez, Enflamasyon, Hematopoietik kök hücre transplantasyonu 


\section{Introduction}

Acute graft-versus-host disease (aGvHD) is one of the major complications of allogeneic hematopoietic stem cell transplantation (HSCT) with significant morbidity and mortality $[1,2]$. Despite the advances in our understanding of the pathogenesis of aGvHD, the mechanisms contributing to the development and severity of aGvHD are not yet fully elucidated [3]. Discovery of biomarkers for aGvHD has provided insight into the complex pathogenesis of aGvHD and suggests novel mechanisms of recipient tissue damage and impaired regenerative capacity for therapeutic targeting $[4,5,6,7,8,9]$. Recent studies have shown that epithelial cell damage, characteristic of aGvHD, develops secondary to vascular endothelial damage caused by alloreactive donor T cells $[10,11]$. Endothelial damage leads to endothelial cell activation and stimulates angiogenesis. Angiogenesis contributes to persistent inflammation leading to clinical presentation of aGvHD. This interaction between inflammation and angiogenesis leads to the development of aGvHD as well as other serious earlyonset complications of HSCT known as vascular endothelial syndromes [12]. Therefore, it has been suggested that the vascular endothelium may be a target for the early diagnosis and treatment of HSCT complications. Levels of circulating angiogenic factors (AFs) associated with tissue repair, including epidermal growth factor (EGF), vascular endothelial growth factor (VEGF), and heparin binding EGF-like growth factor (HB-EGF), have been found to be significantly decreased in patients with aGvHD and steroid-refractory aGvHD compared to patients without aGvHD and those with steroid-responsive aGvHD $[1,10,12]$. On the other hand, endothelial damage and inflammation-related factors such as angiopoietin-2 (Ang2), soluble endoglin, follistatin, and placental growth factor have been shown to increase significantly in patients with aGvHD and steroid-refractory aGvHD $[13,14,15,16,17,18]$. Studies investigating the impact of circulating AFs on aGvHD have mostly been focused on the post-transplant period. However, taking into consideration that AF levels, and especially levels of those AFs involved in endothelial damage/inflammation, can provide useful information about endothelial vulnerability to damage, it might be a beneficial approach to assess AF levels during the pre-transplant period [19]. We propose that patients with alterations in circulating AF levels involved in damage or inflammation during the pre-transplant period would have higher risk for the development of aGvHD.

\section{Materials and Methods}

This study was approved by the Non-Interventional Ethics Committee of Hacettepe University (reference number: GO 18/235-29). Peripheral blood samples were collected before the conditioning regimen (day -9) and after completion of the conditioning regimen (day 0) prior to transplantation. The levels of Ang2, endoglin, and follistatin were studied from the plasma samples of patients and healthy controls simultaneously by Luminex immunoassay method using the Human Premix Multianalyte Kit (RCtD Systems, Cat. \# LXSAH) and Luminex 200 device. The results were analyzed with the Luminex analyzer with the X-Y platform. In addition, serum uric acid, albumin, and $\mathrm{C}$-reactive protein (CRP) levels measured during the pretransplant period (before and after conditioning regimen) were noted as systemic inflammatory markers for the patients.

\section{Statistical Analysis}

Statistical analyses were performed using SPSS 22.0 software (IBM Corp.). The risk factors for aGvHD were examined by logistic regression analysis. Receiver operating characteristic (ROC) curves were constructed for the significant indices predicting the incidence of aGvHD, and the area under the ROC curve (AUC) was calculated to examine index performance.

\section{Results}

Thirty-seven patients ( 19 male and 18 female patients; median age: 6 years, range: $1-22$ years) were included in the study. Seven out of 37 patients underwent allogeneic bone marrow transplantation for non-malignant hematologic diseases (severe aplastic anemia and thalassemia), 13 patients for hematologic malignancies, 14 patients for primary immunodeficiency disorders, and 3 patients for neurometabolic disorders. Overall, $24(65 \%)$ of 37 patients had non-malignant disorders and $13(35 \%)$ had hematologic malignancies. All patients were transplanted from a fully HLA-matched sibling or family donor except one patient who received a bone marrow graft from a partially matched family donor. As the stem cell source, bone marrow was used for 34 (92\%) patients, while peripheral blood was preferred for 3 patients. Among the 37 patients, 33 (89\%) received a busulfan-based or total body irradiation-based myeloablative conditioning regimen. All patients received cyclosporin and low-dose methotrexate for GvHD prophylaxis. Upon successful engraftment in all patients, 16 patients were diagnosed with aGvHD (43\%), whereas only one patient was diagnosed with chronic GrHD. Fifteen out of 16 patients with aGvHD had mild to moderate aGvHD and only one patient had severe aGvHD. Skin findings were reported in 15 patients, liver findings in 5 patients, and gastrointestinal system findings in 3 patients. Seven of 16 patients with aGvHD had a history of engraftment syndrome and 6 patients had a history of hepatic veno-occlusive disease.

First, we compared the pre-conditioning plasma levels of Ang2, endoglin, and follistatin of the 37 patients with the levels of 10 healthy controls. The patients showed significantly increased levels of all three AFs associated with damage and inflammation (Ang2, $2738.3 \pm 367 \mathrm{pg} / \mathrm{mL}$ vs. $867.5 \pm 151 \mathrm{pg} /$ $\mathrm{mL}, \mathrm{p}<0.001$; endoglin, $2149 \pm 215 \mathrm{pg} / \mathrm{mL}$ vs. $1166.5 \pm 239 \mathrm{pg} /$ 
$\mathrm{mL}, \mathrm{p}=0.008$; follistatin, $12200.4 \pm 1093 \mathrm{pg} / \mathrm{mL}$ vs. $5832.9 \pm 732$ $\mathrm{pg} / \mathrm{mL}, \mathrm{p}<0.001)$. Interestingly, the difference between the Ang2 and endoglin levels of patients and controls disappeared after conditioning; only the follistatin levels remained higher in the patients $(11502.6 \pm 772 \mathrm{pg} / \mathrm{mL}$ vs. $5832.9 \pm 732 \mathrm{pg} / \mathrm{mL}, \mathrm{p}<0.001)$. Next, pre- and post-conditioning serum uric acid, albumin, and CRP levels were evaluated. Significant elevations in serum uric acid $(2.47 \pm 0.2 \mathrm{mg} / \mathrm{dL}$ vs. $6.64 \pm 0.4 \mathrm{mg} / \mathrm{dL}, \mathrm{p}<0.001)$ and CRP $(1.77 \pm 1.2 \mathrm{mg} / \mathrm{dL}$ vs. $8.14 \pm 0.7 \mathrm{mg} / \mathrm{dL}, \mathrm{p}<0.001)$ levels were observed after conditioning, while albumin $(3.78 \pm 0.1 \mathrm{~g} / \mathrm{dL}$ vs. $2.9 \pm 0.1 \mathrm{~g} / \mathrm{dL}, \mathrm{p}<0.001)$ decreased in all patients. In order to eliminate the effects of inter-patient variations in AF levels, and to better evaluate the changes in AF levels after conditioning, the index value for each marker was calculated as the ratio of the pre-conditioning levels to post-conditioning levels. Patients with and without aGvHD were compared according the index values of the parameters that showed significant changes after conditioning (Ang2, endoglin, follistatin, uric acid, albumin, and CRP). The Ang 2 index was higher ( 2.56 vs. $1.81, p=0.028$ ) and the albumin index was lower ( 1.19 vs. $1.41, p=0.017$ ) in the patients with aGvHD compared to the patients without aGvHD. The other indices studied did not reveal any significant alterations between the groups (Table 1). This result suggests a relationship between pre-transplant Ang2 levels and aGvHD.

We conducted univariable and multivariable logistic regression analyses to identify significant AFs and/or other inflammatory markers' index values that would be indicative of an increased risk for aGvHD (Table 2). Accordingly, we demonstrated that the pre-transplant Ang2 index was an independent risk factor for aGvHD development ( $p=0.04$, odds ratio: $2.25,95 \%$ confidence interval: 1.03-4.9). In addition, a low pre-transplant albumin index and the diagnosis of hematologic malignancy conferred higher risk of aGvHD $(p<0.05)$. ROC curve analysis was then performed to determine the cutoff and assess the predictive value of the pre-transplant Ang2 index for aGvHD. As shown in Table 3, the cutoff of the Ang2 index in the pre-transplant period for aGvHD was 1.44 with an AUC of $72 \%$, sensitivity of $100 \%$, and specificity of $45 \%$. We observed a difference in the frequency of aGvHD among the patients when compared regarding the Ang2 index cutoff value (above the cutoff: 57\%

Table 1. Comparison of index values of plasma angiogenic factors and inflammatory markers of patients with and without acute graft-versus-host disease (aGvHD).

\begin{tabular}{|c|c|c|c|}
\hline & \multicolumn{3}{|l|}{ aGvHD } \\
\hline Index ${ }^{*}$, median (range) & Present & Absent & $\mathrm{p}$ \\
\hline Angiopoietin-2*** & $2.56(1.52-13.6)$ & $1.81(0.53-3.81)$ & 0.028 \\
\hline Endoglin** & $1.29(0.53-3.13)$ & $1.38(0.48-2.82)$ & 0.63 \\
\hline Follistatin*** & $0.97(0.46-3.39)$ & $1.08(0.43-2.30)$ & 0.86 \\
\hline Uric acid*** & $0.42(0.12-1.27)$ & $0.35(0.12-0.79)$ & 0.26 \\
\hline Albumin ** & $1.19(0.72-1.66)$ & $1.41(0.91-2.14)$ & 0.017 \\
\hline C-reactive protein ${ }^{* * *}$ & $0.22(0.04-0.48)$ & $0.23(0.02-0.60)$ & 0.98 \\
\hline \multicolumn{4}{|c|}{$\begin{array}{l}\text { *Index value: pre-conditioning plasma level/post-conditioning plasma level. } \\
\text { *The t-test was performed in independent groups. } \\
{ }^{* * *} \text { Mann-Whitney } U \text { test in independent groups. Values of } p<0.05 \text { were considered statistically significant. }\end{array}$} \\
\hline
\end{tabular}

\begin{tabular}{|l|l|l|l|l|}
\hline Table 2. Multivariable logistic regression model for acute graft-versus-host disease. \\
\hline Parameters & $\mathbf{p}$ & Odds ratio & \multicolumn{3}{l|}{$\begin{array}{l}\text { Odds ratio, 95\% } \\
\text { confidence interval }\end{array}$} \\
\cline { 4 - 6 } & & & Minimum & Maximum \\
\hline $\begin{array}{l}\text { Primary disease } \\
\text { (malignant/non-malignant) }\end{array}$ & 0.032 & 9.716 & 1.214 & 77.747 \\
\hline Angiopoietin-2 index & 0.043 & 2.245 & 1.027 & 4.905 \\
\hline Albumin index & 0.025 & 0.016 & 0.001 & 0.586 \\
\hline Constant & 0.138 & 41.593 & & \\
\hline
\end{tabular}

Table 3. Optimal threshold for the pre-transplant angiopoietin-2 (Ang2) index for predicting acute graft-versus-host disease.

\begin{tabular}{|l|l|l|l|l|}
\hline Index (pre-/post-conditioning value) & Area under the curve & Cutoff point & Sensitivity (\%) & Specificity (\%) \\
\hline Ang2 & 0.716 & 1.44 & 100 & 45 \\
\hline
\end{tabular}


vs. below the cutoff: $0 \%, p=0.004)$. These results suggest that pre-transplant Ang2 index is predictive of aGvHD.

\section{Discussion}

Recent studies indicate the importance of the crosstalk between inflammation and angiogenesis in the pathogenesis and treatment outcomes of aGvHD $[20,21,22]$. However, most studies have mainly focused on the diagnostic/prognostic value of endothelial activation markers in patients who already present with aGvHD, rather than the possible implication of endothelial injury/inflammation marker profiles in the pretransplant evaluation of patients $[23,24,25]$.

Accordingly, we found elevated levels of Ang2, follistatin, and endoglin even prior to conditioning, indicating ongoing subtle inflammation/occult tissue injury. Interestingly, the levels of Ang2 and endoglin returned to normal while the level of follistatin, which predominantly reflects tissue damage and unresolved inflammation [26], remained high after conditioning. Although it seems controversial, post-conditioning alterations in AF levels have been reported in transplant recipients, suggesting that angiogenic response mechanisms in the early transplant period at the onset of inflammation may be different from those effective during the course of aGvHD $[13,27,28]$. Ang2 is a Tie2-binding antagonist of angiopoietin-1 that disrupts Ang1-mediated vessel integrity and reflects the susceptibility of the endothelium to damage $[29,30]$. In the present study, we showed that elevated pre-transplant Ang2 index was strongly associated with the risk of aGvHD together with low albumin index. Our determined cutoff value of $1.44 \mathrm{mg} / \mathrm{dL}$ for the pre-transplant Ang2 index, derived from ROC analysis, was predictive of aGvHD development and a difference in the frequency of aGvHD was observed among the patients when compared regarding the Ang2 index cutoff value. Hence, these results suggest that Ang2 promotes a more vigorous endothelial stress response to local alloreactive T-cell attack in patients with high pre-transplant Ang2 levels who later develop aGvHD. Similarly, recent studies have shown a continued increase in Ang2 levels for up to four weeks along with an increase in proinflammatory cytokines after allogeneic HSCT. Patients with high-grade aGvHD also exhibited significant increases in Ang2 levels compared to patients with low-grade aGvHD, and this increase was strongly associated with aGvHD severity and mortality [31]. In another study conducted by Luft et al. [21], patients with refractory aGvHD already showed significantly increased Ang2 levels before transplantation. They also found elevated Ang2/NEGF ratios after aGvHD onset in steroidrefractory but not in steroid-sensitive patients [21]. In this context, Porkholm et al. [18] concluded that pre-transplant high Ang2 plasma levels were associated with increased risk of intestinal aGvHD and non-relapse mortality in a pediatric study.

\section{Conclusion}

Our results suggest that pre-transplant evaluation of plasma Ang2 levels along with inflammatory status even before conditioning might be a reliable indicator of endothelial vulnerability. The pre-transplant Ang2 index as an independent risk factor for aGvHD seems to be a promising candidate for estimating the risk of aGvHD in allogeneic HSCT recipients. However, there is still a need for mechanistical studies to understand the precise role of angioregulatory factors in the pathogenesis of aGvHD.

\section{Ethics}

Ethics Committee Approval: This study was approved by the Non-Interventional Ethics Committee of Hacettepe University (reference number: G0 18/235-29).

\section{Authorship Contributions}

Concept: F.V.O., D.C.; Design: F.V.O., D.C.; Data Collection or Processing: Ö.S., D.C.; Analysis or Interpretation: Ö.S., I.C.Z., B.A.; Writing: Ö.S., I.C.Z., B.A., J.K., D.Ç., F.V.O.

Conflict of Interest: No conflict of interest was declared by the authors.

Financial Disclosure: This study was supported by the Hacettepe University Scientific Research Projects Coordination Unit (project number: THD-2019-17870).

\section{References}

1. Magenau J, Runaas L, Reddy P. Advances in understanding the pathogenesis of graft-versus-host disease. Br J Haematol 2016;173:190-205.

2. Jagasia M, Arora M, Flowers ME, Chao NJ, McCarthy PL, Cutler CS, UrbanoIspizua A, Pavletic SZ, Haagenson MD, Zhang MJ, Antin JH, Bolwell BJ, Bredeson C, Cahn JY, Cairo M, Gale RP, Gupta V, Lee SJ, Litzow M, Weisdorf DJ, Horowitz MM, Hahn T. Risk factors for acute GVHD and survival after hematopoietic cell transplantation. Blood 2012;119:296-307.

3. Blazar BR, Murphy WJ, Abedi M. Advances in graft-versus-host disease biology and therapy. Nat Rev Immunol 2012;12:443-458.

4. He FC, Holtan SG. Biomarkers in graft-versus-host disease: from prediction and diagnosis to insights into complex graft/host interactions. Curr Hematol Malig Rep 2018;13:44-52.

5. Paczesny S. Biomarkers for posttransplantation outcomes. Blood 2018;131:2193-2204.

6. McDonald GB, Tabellini L, Storer BE, Lawler RL, Martin PJ, Hansen JA. Plasma biomarkers of acute GVHD and nonrelapse mortality: predictive value of measurements before GVHD onset and treatment. Blood 2015;126:113-120.

7. Dietrich $\mathrm{S}$, Falk CS, Benner A, Karamustafa S, Hahn E, Andrulis M, Hegenbart $U$, Ho AD, Dreger P, Luft T. Endothelial vulnerability and endothelial damage are associated with risk of graft-versus-host disease and response to steroid treatment. Biol Blood Marrow Transplant 2013;19:22-27.

8. Balakrishnan B, Illangeswaran RSS, Rajamani BM, Pai AA, Raj IX, Paul DZ, Lakshmi K, Mani T, Mohanan E, Kulkarni U, Devasia AJ, Fouzia NA, Korula A, Abraham A, Srivastava A, Mathews V, Paczesny S, George B, Balasubramanian P. Prognostic plasma biomarkers of early complications and graft-versushost disease in patients undergoing allogeneic hematopoietic stem cell transplantation. EJHaem 2020;1:219-229. 
9. Major-Monfried $H$, Renteria AS, Pawarode $A$, Reddy $P$, Ayuk $F$, Holler E, Efebera YA, Hogan WJ, Wölfl M, Qayed M, Hexner EO, Wudhikarn K, Ordemann R, Young R, Shah J, Hartwell MJ, Chaudhry MS, Aziz M, Etra A, Yanik GA, Kröger N, Weber D, Chen YB, Nakamura R, Rösler W, Kitko CL, Harris AC, Pulsipher M, Reshef R, Kowalyk S, Morales G, Torres I, Özbek U, Ferrara JLM, Levine JE. MAGIC biomarkers predict long-term outcomes for steroid-resistant acute GVHD. Blood 2018;131:2846-2855.

10. Carreras E, Diaz-Ricart M. Early complications of endothelial origin. In: Kröger ECDM (ed). The EBMT Handbook: Hematopoietic Stem Cell Transplantation and Cellular Therapies. Cham, Springer, 2019.

11. Ali AM, DiPersio JF, Schroeder MA. The role of biomarkers in the diagnosis and risk stratification of acute graft-versus-host disease: a systematic review. Biol Blood Marrow Transplant 2016;22:1552-1564.

12. Carreras $E$, Diaz-Ricart M. The role of the endothelium in the shortterm complications of hematopoietic SCT. Bone Marrow Transplant 2011;46:1495-1502.

13. Holtan $\mathrm{SG}$, Arora M. Angiogenic factors and inflammation in steroidrefractory acute graft-vs-host disease. Transl Res 2016;167:80-87.

14. Tatekawa S, Kohno A, Ozeki K, Watamoto K, Ueda N, Yamaguchi $Y$, Kobayashi T, Yokota I, Teramukai S, Taniwaki M, Kuroda J, Morishita Y. A novel diagnostic and prognostic biomarker panel for endothelial cell damage-related complications in allogeneic transplantation. Biol Blood Marrow Transplant 2016;22:1573-1581.

15. Blix ES, Husebekk A. Raiders of the lost mark - endothelial cells and their role in transplantation for hematologic malignancies. Leuk Lymphoma 2016;57:2752-2762.

16. Lindas R, Tvedt TH, Hatfield KJ, Reikvam H, Bruserud O. Preconditioning serum levels of endothelial cell-derived molecules and the risk of posttransplant complications in patients treated with allogeneic stem cell transplantation. J Transplant 2014;2014:404096.

17. Min CK, Kim SY, Lee MJ, Eom KS, Kim YJ, Kim HJ, Lee S, Cho SG, Kim DW, Lee JW, Min WS, Kim CC, Cho CS. Vascular endothelial growth factor (VEGF) is associated with reduced severity of acute graft-versus-host disease and nonrelapse mortality after allogeneic stem cell transplantation. Bone Marrow Transplant 2006;38:149-156.

18. Porkholm M, Bono P, Saarinen-Pihkala UM, Kivivuori SM. Higher angiopoietin-2 and VEGF levels predict shorter EFS and increased nonrelapse mortality after pediatric hematopoietic SCT. Bone Marrow Transplant 2013;48:50-55.

19. Riesner $K$, Shi $Y$, Jacobi $A$, Kräter $M$, Kalupa M, McGearey $A$, Mertlitz $S$, Cordes S, Schrezenmeier JF, Mengwasser J, Westphal S, Perez-Hernandez D, Schmitt C, Dittmar G, Guck J, Penack 0. Initiation of acute graft-versushost disease by angiogenesis. Blood 2017;129:2021-2032.

20. Corbacioglu $S$, Carreras $E$, Ansari M, Balduzzi A, Cesaro S, Dalle JH, Dignan F, Gibson B, Guengoer T, Gruhn B, Lankester A, Locatelli F, Pagliuca A, Peters C, Richardson PG, Schulz AS, Sedlacek P, Stein J, Sykora KW, Toporski J, Trigoso E, Vetteranta K, Wachowiak J, Wallhult E, Wynn R, Yaniv I, Yesilipek A, Mohty $\mathrm{M}$, Bader P. Diagnosis and severity criteria for sinusoidal obstruction syndrome/veno-occlusive disease in pediatric patients: a new classification from the European society for blood and marrow transplantation. Bone Marrow Transplant 2018;53:138-145.

21. Luft $T$, Dietrich $S$, Falk $C$, Conzelmann $M$, Hess $M$, Benner $A$, Neumann $F$, Isermann B, Hegenbart U, Ho AD, Dreger P. Steroid-refractory GVHD: T-cell attack within a vulnerable endothelial system. Blood 2011;118:1685-1692.

22. Holtan SG, Verneris MR, Schultz KR, Newell LF, Meyers G, He F, DeFor TE, Vercellotti GM, Slungaard A, MacMillan ML, Cooley SA, Blazar BR, Panoskaltsis-Mortari A, Weisdorf DJ. Circulating angiogenic factors associated with response and survival in patients with acute graft-versushost disease: results from Blood and Marrow Transplant Clinical Trials Network 0302 and 0802. Biol Blood Marrow Transplant 2015;21:1029-1036.

23. Chaidos A, Kanfer $E_{1}$ Apperley JF. Risk assessment in haemotopoietic stem cell transplantation: disease and disease stage. Best Pract Res Clin Haematol 2007;20:125-154.

24. Reikvam H, Mosevoll KA, Melve GK, Günther CC, Sjo M, Bentsen PT, Bruserud $\emptyset$. The pretransplantation serum cytokine profile in allogeneic stem cell recipients differs from healthy individuals, and various profiles are associated with different risks of posttransplantation complications. Biol Blood Marrow Transplant 2012;18:190-199.

25. Gratwohl A, Passweg J, Baldomero H, Orchard K, Kröger N, Snowden $J A$; Joint Accreditation Committee (JACIE) of the International Society for Cellular Therapy Europe (ISCT), the European Society for Blood, Marrow Transplantation (EBMT). Conditioning intensity before allogeneic haematopoietic stem cell transplantation: a quality control audit. $\mathrm{Br} \mathrm{J}$ Haematol 2021;192:e151-e154.

26. de Kretser DM, O'Hehir RE, Hardy CL, Hedger MP. The roles of activin A and its binding protein, follistatin, in inflammation and tissue repair. Mol Cell Endocrinol 2012;359:101-106.

27. Palomo M, Diaz-Ricart M, Carbo C, Rovira M, Fernandez-Aviles F, Escolar G, Eissner $G$, Holler $E$, Carreras E. The release of soluble factors contributing to endothelial activation and damage after hematopoietic stem cell transplantation is not limited to the allogeneic setting and involves several pathogenic mechanisms. Biol Blood Marrow Transplant 2009;15:537-546.

28. Penack $\mathrm{O}$, Socié $\mathrm{G}$, van den Brink MR. The importance of neovascularization and its inhibition for allogeneic hematopoietic stem cell transplantation. Blood 2011;117:4181-4189.

29. Fiedler U, Reiss Y, Scharpfenecker M, Grunow V, Koidl S, Thurston G, Gale NW, Witzenrath M, Rosseau S, Suttorp N, Sobke A, Herrmann M, Preissner KT, Vajkoczy P, Augustin HG. Angiopoietin-2 sensitizes endothelial cells to TNF-alpha and has a crucial role in the induction of inflammation. Nat Med 2006;12:235-239.

30. Kreuter $M$, Kropff $M$, Fischaleck A, Junker K, Gerss J, Heinecke A, Lindermann M, Reinmuth N, Berdel WE, Mesters RM, Thomas M. Prognostic relevance of angiogenesis in stage III NSCLC receiving multimodality treatment. Eur Respir J 2009;33:1383-1388.

31. Nomura $S$, Ishii $K$, Inami $N$, Kimura $Y$, Uoshima $N$, Ishida $H$, Yoshihara $T$ Urase $F$, Maeda $Y$, Hayashi K. Evaluation of angiopoietins and cell-derived microparticles after stem cell transplantation. Biol Blood Marrow Transplant 2008;14:766-774. 